\title{
EN LOS ATARDECERES DE LA CARNE...
}

\section{Elena PALLARÉS}

A José Enrique Martínez

Écrire commence avec le regard d'Orphée Maurice Blanchot

\section{I}

En los atardeceres de la carne

mi escritura oscurece un objeto de amor.

Los labios de la tierra sangran besos

cuando ocultas en páginas de hierba

se desvelan palabras como muerte.

Sobrenadan las aguas de un arroyo

cadáveres de letras cuyas combinaciones

dibujan las mil móviles figuras

de su nombre mordido en flor de nadie.

La fronda del dolor hace a la noche.

La noche, extraña madre, de sus pechos

de bruma amamantaba al hijo

de negra leche.

\section{II}

Por desmontar un porvenir

construido de días sin mañana

yo le rasgué el telón al teatro del tiempo

con el cuchillo húmedo del ojo 
310 Tropelías. Revista de Teoría de la Literatura y Literatura Comparada, número extraordinario 1 (2017) Elena Pallarés

en el que aún se refleja

aquel que al alma tanto duele

y hambrienta de tu noche recorría

sus largos corredores

—iperegrina me dicen del amor!-

y de abismo en abismo,

de pisada en pisada,

de huella en huella,

yo, la rastreadora de los pasos perdidos, descendí a los infiernos.

Esas voces que llaman a las tantas

a las puertas del bosque de las sombras

penas de ausencia son, penas de ausencia:

¡Ah de la noche!

Y es mi lengua esa llama con que llama el amor.

Arde la noche infecta, contagiada en mi incendio

-ella, la obscena noche de las almas,

sus pétalos inexplorados

me abría sin pudor-.

Yo, la cronista,

como ofrenda a los dioses

traigo mis manos, dije,

llenas de ramas de caducidad.

Déjame silenciar cómo era tu presencia,

amordazar los días que habitamos el cielo,

callar todos tus nombres

$\mathrm{y}$, aunque por una vez no exageró el poeta,

decirte solamente la palabra

que daba por perdida el ángel negro:

amor. 
Desde el pétreo párpado

de la estatua de aquel ángel caído

huía una encendida lágrima.

A ti, parda sombra de sombras, te ocultaba la nada, el caos, tras el bullicio intraducible del oscuro teatro de los ayes hasta que mi mirada te devuelve a la palabra y a los días y el de color de nieve otra vez fuiste -durante unos instantes un chorro de blancura iluminó el infierno-

Siempre de huella en huella, de pisada en pisada ascendía el abismo un corazón tras otro corazón de regreso en regreso.

\section{V}

La palabra es un pájaro que rompiendo las rejas —una gota de sangre sobre el herido picoescapa de la jaula del silencio hacia la libertad.

Desde lo alto del árbol del lenguaje al poeta le ofrece desvelarle la cifra de los juegos de letras a cambio de su alma. Yo pacté con el pájaro tu nombre y al transgredir la ley para llamarte 
312 Tropelías. Revista de Teoría de la Literatura y Literatura Comparada, número extraordinario 1 (2017) Elena Pallarés

vi en tu noche la noche del infierno,

vi agarrada tu mano a una mano de sombra

y vi mi propia sed del mal

— mi adicción a volverte material de poema-

desgarrando la cara oculta de tus muslos

- ah, noche oscura de la carne-

al grabar en tu piel caligrafías

que tras formar tu nombre

a cada filigrana lo transforman.

\section{VI}

Descuartizan mis ojos en letras a tu nombre

al tatuarte en el vientre signos desconocidos, garabatos de amor y muerte, garabatos.

Tu mirada es la cifra que me vela,

la que sella mi boca

con lacre rojo,

la que cierra mi pecho a cal y canto,

se quejó el corazón colgado por los pies

de una rama del árbol del deseo

como un fruto mordido

por los dientes del ojo.

Hay ojos traicioneros,

ojos que sacrifican los días por venir

en aras de un instante de escritura.

Hay miradas culpables,

ojos que matan.

VII

Invisible te vi, te oí sin voz

y te toqué sin cuerpo

en tu ausencia de sombra 
— ese saber estar en tu no estar-

y al besar en tus labios el vacío

supe al fin a que la muerte sabía a transparencia.

Y nuestros corazones

latieron otra vez a contratiempo.

Y yo volví a ser la vagabunda,

esa figura errante

que de abismo en abismo,

de infierno a infierno,

detrás de ti como alma en pena vaga.

Y tú de nuevo fuiste la silueta

de un paseante

hacia desconocidas lejanías

en donde crece el árbol de los nombres perdidos

—no florece la letra de sus ramas estériles

ni la rosa ni el pájaro-.

\section{VIII}

El ala de la muerte

-invisible pañuelo del adiós-

pasó sobrevolando la palabra

nosotros que deshecha en letras

cayó sobre el paisaje como copos de olvido.

Al llegar el ocaso de las identidades, gastada día a día la sustancia que nos hacía ser nosotros, decías - y tu voz era un mero accidente en las gargantas de la historia-, cuando el viento se lleva al más allá del corazón

nuestros nombres caídos del árbol del otoño como crepusculares pájaros

y las personas 
314 Tropelías. Revista de Teoría de la Literatura y Literatura Comparada, número extraordinario 1 (2017) Elena Pallarés

- las personas del verbo-

cobijan sus pronombres de la lluvia

bajo los soportales de unas conjugaciones

en que no volveremos a estar juntos,

me pierde tu mirada.

Después mudo y ritual te fuiste

hacia la transparencia de una estrella o una letra. 